Rolf Lauber PhD, Bruno Seeberger MD, Alex Martin Zbinden MD

\title{
Carbon dioxide analysers: accuracy, alarm limits and effects of interfering gases
}

Six mainstream and twelve sidestream infrared carbon dioxide $\left(\mathrm{CO}_{2}\right)$ analysers were tested for accuracy of the $\mathrm{CO}_{2}$-display value, alarm activation and the effects of nitrous oxide $\left(\mathrm{N}_{2} \mathrm{O}\right)$, oxygen $\left(\mathrm{O}_{2}\right)$ and water vapour according to the ISO Draft International Standard (DIS) \#9918. Mainstream analysers (Mtype): Novametrix Capnogard 1265; Hewlett Packard HP M1166A (CO-module HP M1016A); Datascope Passport; Marquette Tramscope 12; Nellcor Ultra Cap N-6000; Hellige Vicom-sm SMU 611/612 ETC. Sidestream analysers: Brüel \& Kjaer Type 1304; Datex Capnomac II; Marquette MGA-AS; Datascope Multinex; Ohmeda 4700 OxiCap (all type Sl: respiratory cycles not demanded); Biochem BCI 9000; Bruker BCI 9100; Dräger Capnodig and PM 8020; Criticare Poet II; Hellige Vicom-sm SMU 611/612 A-GAS (all type S2: respiratory cycles demanded). The investigations were performed with premixed test gases $(2.5,5,10$ vol\%, error $\leq 1 \%$ rel.). Humidification $\left(37^{\circ} \mathrm{C}\right)$ of gases were generated by a Dräger Aquapor. Respiratory cycles were simulated by manually activated valves. All monitors complied with the tolerated accuracy bias in $\mathrm{CO}_{2}$ reading ( $\leq 12 \%$ or $4 \mathrm{~mm} \mathrm{Hg}$ of actual test gas value) for wet and dry test gases at all concentrations, except that the Marquette MGA-AS exceeded this accuracy limit with wet gases at 5 and 10 vol\% $\mathrm{CO}_{2}$. Water condensed in the metal airway adapter of the HP M1166 A at $37^{\circ} \mathrm{C}$ gas temperature but not at $30^{\circ} \mathrm{C}$. The Servomex 2500 (nonclinical reference monitor), Passport (M-type), Multinex (S1-type) and Poet II (S2-type)

\section{Key words}

CARBON DIOXIDE: end-tidal, measurement, monitoring; MEASUREMENT TECHNIQUES: capnometry; MONITORING: carbon dioxide.

From the Institute for Anaesthesiology and Intensive Care, Section of Research, University Hospital, 3010 Bern, Switzerland.

Address correspondence to: Dr. R. Lauber, Institute for Anaesthesiology and Intensive Care, Section of Research, University Hospital, 3010 Bern, Switzerland. Accepted for publication 8th March, 1995. showed the least bias for dry and wet gases. Nitrous oxide and $\mathrm{O}_{2}$ had practically no effect on the Capnodig and the errors in the others were max. $3.4 \mathrm{mmHg}$, still within the tolerated bias in the DIS (same as above). The difference between the display reading at alarm activation and the set point was in all monitors (except in the Capnodig: bias $1.75 \mathrm{mmHg}$ at 5 vol\% $\mathrm{CO}_{2}$ ) below the tolerated limit of the DIS (difference $\leq 0.2$ vol\%). The authors conclude that the tested monitors are safe for clinical use (except those failing the DIS limits). The accuracy of the $\mathrm{CO}_{2}$-reading (average of mean absolute bias) is better in the M-type than in the S1-or S2-type analysers although no statistical (nor clinical) significant differences could be detected. Most manufacturers work with stricter limits than those proposed by the DIS.

Des analyseurs de gaz carbonique $\left(\mathrm{CO}_{2}\right)$ à infrarouge dont six à soutirage latéral et 12 de courant central sont évalués au regard de la précision, de l'activation des alarmes et des effets du protoxyde d'azote $\left(\mathrm{N}_{2} \mathrm{O}\right)$, de l'oxygène $\left(\mathrm{O}_{2}\right)$ et de la vapeur d'eau conformément à la norme internationale ISO (DIS) 9918. Les analyseurs de courant central sont les suivants: (Type-M): Novametrix Capnogard 1265; Hewlett Packard HP M1166A ( $\mathrm{CO}_{2}$ module HP M1016A); Datascope Passport; Marquette Tramscope 12; Nellcor Ultra Cap N-6000; Hellige Vicom-sm SMU 611/612 ETC. Les analyseurs à soutirage latéral: Brüel \& Kjaer Type 1304; Datex Capnomac II; Marquette MGAAS; Datascope Multinex; Ohmeda 4700 OxiCap (tous de type SI: sans demande de cycle respiratoire); Biochem BCI 9000; Bruker BC19100; Dräger Capnodig et PM 8020; Criticare Poet II; Hellige Vicom-sm SMU 611/612 A-Gas (tous de type S2: avec demande de cycle respiratoire). Les études sont réalisées avec des gaz étalons prémélangés $(2,5,5,10$ vol.\%, erreur relative $\leq 1 \%)$. Les gaz sont humidifiés $(37 \%$ C) grâce à un Dräger Aquapor. Les cycles respiratoires sont simulés par des valves actionnées manuellement. Par rapport au biais de tolérance, tous les capnographes sont précis pour la lecture du $\mathrm{CO}_{2}(\leq 12 \%$ ou $4 \mathrm{mmHg}$ de la valeur du gaz étalon) pour les gaz secs et humidifiés entre 5 et $10 \%$ en vol. de $\mathrm{CO}_{2}$. L'eau se condense sur le raccord métallique du HP M1166 A à $37^{\circ} \mathrm{C}$ mais non à $30^{\circ} \mathrm{C}$. Le Servomex 2500 (moniteur de référence non clinique), Passport (Type M) Multinex (Type SI) et Poet II (Type 
S2) sont ceux qui offrent le moins de biais pour les gaz secs et humides. Le protoxyde d'azote et $\mathrm{l}^{\prime} \mathrm{O}_{2}$ n'ont pratiquement pas dinfluence sur le Capnodig et les erreurs pour les autres capnographes sont au maximum de $3,4 \mathrm{mmHg}$, ce qui est toujours en deçà du biais toléré par le DIS. La différence entre l'affichage et l'activation de l'alarme pour un niveau donné est la même pour tous les moniteurs (à l'exception du Capnodig: biais $1,75 \mathrm{mmHg}$ pour un vol. $\mathrm{CO}_{2} 5 \%$ ) sous la limite tolérée du DIS (différence $\leq 0,2$ vol\%). Les auteurs concluent que les moniteurs mis à l'épreuve sont satisfaisants pour l'usage clinique (excepté ceux qui sont en deçà des limites déterminées par le DIS). La précision de la lecture du $\mathrm{CO}_{2}$ (la moyenne du biais absolu) est supérieure pour les appareils de type $M$ aux analyseurs de type S1 et $S 2$ bien qu'aucune différence statistique (ou clinique) n'ait été décelée. La plupart des manufacturiers utilisent des limites plus strictes que celle que recommande le DIS.

Capnography has gained great popularity over the last ten years. 1 The measurement of carbon dioxide $\left(\mathrm{CO}_{2}\right)$ in the respiratory gases has become a standard for basic monitoring in the operating room and intensive care units throughout the world. ${ }^{2-5}$ The American Society of Anesthesiologists (ASA) revised the standards for basic intraoperative monitoring in October 1993. The new standard recommends that operating rooms should be equipped with oxygen $\left(\mathrm{O}_{2}\right)$ analyser (with a low $\mathrm{O}_{2}$ concentration limit alarm), pulse oximetry and encourages $\mathrm{CO}_{2}$ monitoring (strongly recommended after tracheal intubation). ${ }^{6}$ The Canadian Anaesthetists' Society guidelines call for the use of capnographs as a required monitor. More than 20 different types of infrared $\mathrm{CO}_{2}$ analysers are now available world-wide. All new models are able to display the $\mathrm{CO}_{2}$ waveform continuouly using varying display formats. 7,8 The multigas analysers and the majority of capnometers are sidestream analysers, ${ }^{9}$ where a portion of respired gases is diverted with a suction pump from the sampling site through a sampling tube to the sensor. The mainstream technique (the heated sensor is placed directly in the breathing line) has, however, regained great interest. The light and small airway sensors now offer several advantages, especially a fast response time that is suitable for paediatric monitoring. ${ }^{10,11}$ The topic of capnometry has been reviewed in depth. ${ }^{12-15}$ Raemer et al. have explored technical causes of errors in end-tidal $\mathrm{CO}_{2}\left(\mathrm{PETCO}_{2}\right)$ measurement and compared different commercially available infrared analysers including one Raman spectrometer and one stand-alone quadrupole mass spectrometer. ${ }^{16}$

The Draft International Standard (DIS) 9918 of the International Standard Organisation (ISO): "Capnometers for use with humans; requirements", ${ }^{17}$ which will lead to the European Norm 864, proposes a series of test methods and limits which a commercially available carbon dioxide analyser should meet.

The aim of this study was to investigate the feasibility of DIS \#9918 and to investigate 18 currently available $\mathrm{CO}_{2}$ analysers (six are recently developed mainstream analysers) for:

- Accuracy of PETCO $\mathrm{P}_{2}$ reading with dry and wet gases; effect of the interfering gases nitrous oxide $\left(\mathrm{N}_{2} \mathrm{O}\right)$ and oxygen $\left(\mathrm{O}_{2}\right)$.

DIS: $\mathrm{CO}_{2}$ reading shall be $\pm 12 \%$ of the actual gas value or $\pm 4 \mathrm{mmHg}$, whichever is greater, over the full range.

- Accuracy of alarm limits.

DIS: The difference between the alarm set point and the $\mathrm{CO}_{2}$ reading when the alarm is activated shall not exceed 0.2 vol $\%$.

\section{Methods}

The monitors were divided into three groups. Type $\mathbf{M}$ : mainstream monitors, type S1: sidestream monitors with continuous $\mathrm{PETCO}_{2}$ measurement (respiratory cycles not demanded) and type S2: sidestream monitors with noncontinuous $\mathrm{PETCO}_{2}$ measurement (respiratory cycles demanded). The Servomex 2500 precision infrared analyser served as a nonclinical reference device. All monitors were commercially available (in Europe) and factory new. Technical data of the monitors are shown in the Appendix (Appendix, Table IV to VI).

\section{General}

Each instrument was switched on at least one hour before use and was calibrated according to the manufacturer's advice. All S1- and S2-type monitors (except Poet II) have to be calibrated with a gas mixture (containing $\mathrm{CO}_{2}$, $\mathrm{N}_{2} \mathrm{O}, \mathrm{O}_{2}$, volatile anaesthetic or freon). M-type monitors are calibrated with reference cells (except Tramscope 12, Ultra Cap, Vicom ETC) where, together with Poet II and Servomex, $\mathrm{CO}_{2}$ mixtures with balance nitrogen are used. Laboratory and gas temperatures as well as the barometric pressure $\left(\mathbf{P}_{\mathbf{b}}\right)$ were recorded continuously during each calibration and measuring procedure (Therm 3480-6 electronic precision thermocouple thermometer (Ahlborn, Holzkirchen/D); precision aneroid barometer (Barigo/D)). Test gases proposed by the ISO draft standard were used: $0.0,2.5,5.0$ and 10.0 vol\% $\mathrm{CO}_{2}$ balance nitrogen $\left(\mathrm{N}_{2}\right)$ or air. The gas mixtures were gravimetrically produced (Carbagas, Bern, Switzerland) according to the ISO Norm $6142^{18}$ with an error of $\leq 0.03$ vol\%. The pressure of the compressed gases was reduced from $15 \mathrm{MPa}$ to $300 \mathrm{kPa}$ using reduction valves and dosed via rotameters. The gases then passed to a sample dis- 


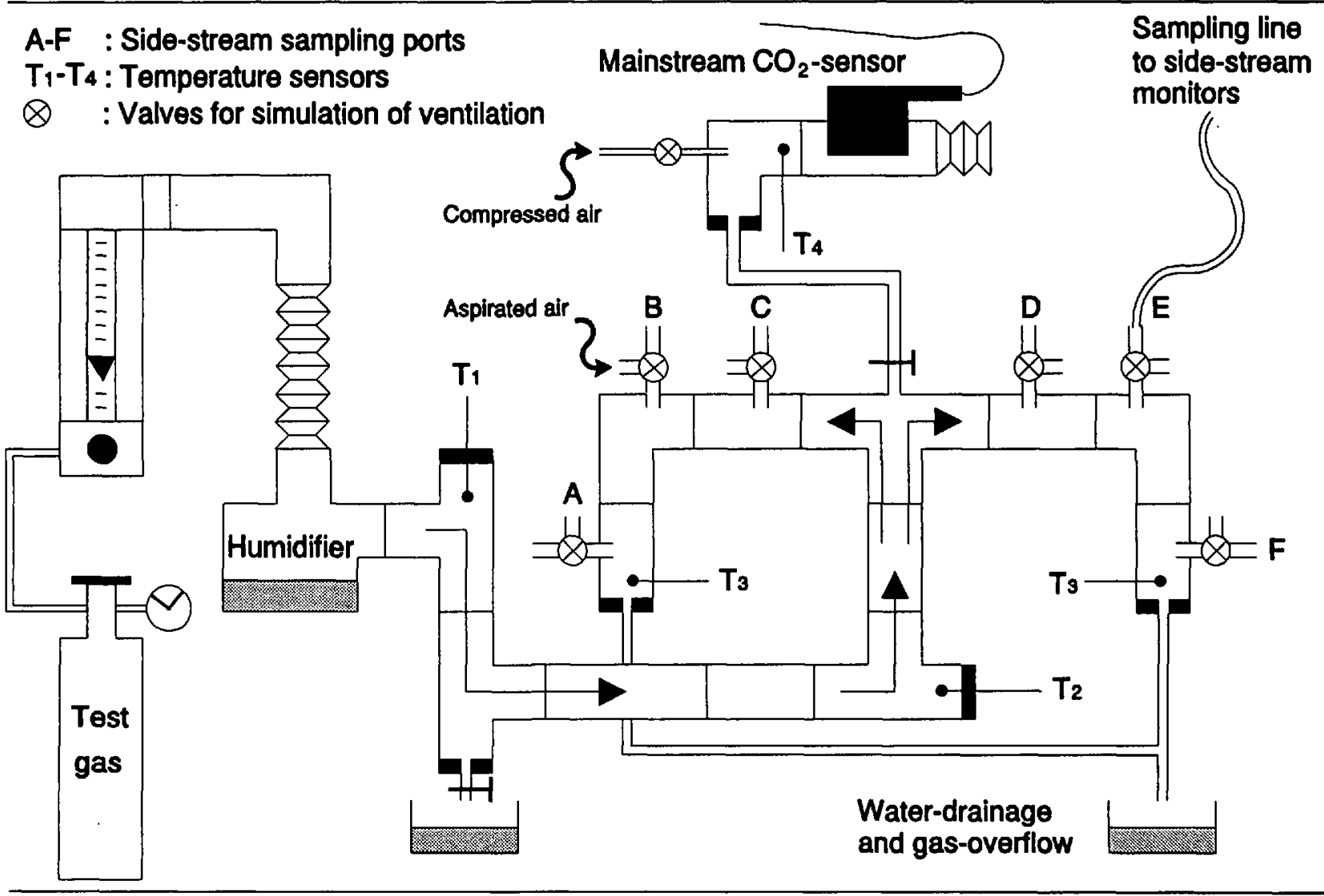

FIGURE I Schematic diagram of the test gas humidifying and distributing system. Mainstream and sidestream monitors (six simultaneously) were checked separately. Three-way taps (A-F) were used to simulate respiratory cycling. $T_{1}$ to $T_{4}$ are temperature measuring ports. The whole tubing system is thermically insulated.

tribution line consisting of a series of six standard sample connectors for the sidestream devices, or were conducted directly to the measuring cuvette in M-type monitors (see Figure 1). The selected measurement unit was $\mathrm{mmHg}$ unless otherwise stated. The actual partial pressure $\left(\mathrm{PCO}_{2}\right)$ of the dry test gases was simultaneously computed $\left(\mathrm{PCO}_{2}=\mathrm{P}_{\mathrm{b}}[\mathrm{mmHg}] \cdot\right.$ test gas concentration [vol $\%] / 100$ ). Sidestream and mainstream monitors were tested on separate occasions. Since the S2- and M-type monitors will display $\mathrm{PETCO}_{2}$ only when one or more respiratory cycles are detected, changes of $\mathrm{CO}_{2}$ concentration (cycles) were generated as follows. Sidestream devices: modified three-way taps were installed at the beginning of the sampling line and manually switched to either air or test gas sampling. Mainstream devices: The airway adapter was flushed periodically with air obtained from an oil-free compressed air supply (Jun Air 2000, Norresundby, Denmark), using a Herion-5/2-switchvalve (Vektor AG, Volketswil, Switzerland) installed before the sensor (Figure 1). Normal capnograms, with a baseline (during air phase) showing a $\mathrm{CO}_{2}$ concentration of zero and a horizontal plateau (during test gas phase) with steady state $\mathrm{PETCO}_{2}$ values, were obtained after three cycles and a sampling time ratio between air and test gas of $1: 10$ at a frequency of $6-10$ cycles $\cdot \min ^{-1}$. In the S1-type monitors displayed $\mathrm{PETCO}_{2}$ values remained stable, whether respiratory cycles occurred or not.

Each measurement was repeated four times, both in ascending and descending order of $\mathrm{CO}_{2}$ test gas concentration (taking into account a possible hysteresis effect), using both air and nitrogen as balance gas: $100 \% \mathrm{~N}_{2}$ or air was used as zero gas concentration. The bias (display value - test gas concentration) and its standard deviation $(\mathrm{mmHg})$ were computed. A small bias means high accuracy. In each monitor group (M, S1, S2) the mean absolute bias (MAB, all four concentrations) and the average (all monitors) of $\mathrm{MAB}$ was computed and compard with a $t$ test $(P \leq 0.05)$ to reveal a possible difference. The Servomex analyser was left switched on during the measuring period, continuously checking the test gas concentration at the sampling sites of the distributing line. 
Accuracy with dry test gases

In sidestream devices the gas flow rate was adjusted about $300 \mathrm{ml} \cdot \mathrm{min}^{-1}$ above the total sum of the sampling flows of the investigated monitors $\left(150-250 \mathrm{ml} \cdot \mathrm{min}^{-1}\right.$ each) and the resulting overflow was conducted to the atmosphere via a short tube. The overflow was verified by briefly submerging the end of the tube into a receptacle of water watching for bubbles. For the M-type monitors the gas flow rate was kept at a constant $2 \mathrm{~L} \cdot \mathrm{min}^{-1}$.

\section{Interference by water vapour}

To test the effect of water vapour the same test gas mixtures, fully saturated with water vapour in a heated cascade humidifier (Aquapor, Dräger, Lübeck, Germany) resulting in an end temperature of $37 \pm 2^{\circ} \mathrm{C}\left(\mathrm{T}_{3}, \mathrm{~T}_{4}\right.$ in Figure 1), were used. In order to keep the temperature of the saturated gases within narrow limits, the T-shaped sampling unit was thermically isolated with cotton wool and tinfoil and provided with four temperature measuring ports $\left(T_{1}\right.$ to $T_{4}$ in Figure 1). Temperatures, $T_{1}$ and $T_{2}$ were measured by mercury thermometers; $T_{3}$ and $T_{4}$ represent the measurement points at the sampling inlet of the sidestream devices and at the mainstream sensor site. Temperature and humidity of $T_{3}+T_{4}$ were measured by a calibrated capacitive hygrometer combined with a thermocouple temperature probe (Rotronic, Zürich, Switzerland; series 100 , range $1-100^{\circ} \mathrm{C}$ and $1-100 \%$ relative humidity), which had previously been calibrated according to the manufacturer's instruction. Voltages at the analogue output of the probes were measured by precision digital voltmeters (Metex M-4630), which had previously been calibrated in the range of 0 to 10 volts with a calibrator (PJN 5210, AOIP, Evry Cedex, France). The gas flow rate through the humidifier (setting at position 2 of a scale 1-12) was kept at $1.5 \mathrm{~L} \cdot \mathrm{min}^{-1}$ which resulted in constant temperature readings after $30 \mathrm{~min}$.

\footnotetext{
Measuring procedure

After six hours of continuous sampling of fully saturated air at $37^{\circ} \mathrm{C}$ by the sidestream devices (according to the DIS proposal), accuracy tests for wet gases were performed and the results computed in the same way as for dry gases, making the corresponding correction for the effect of gas dilution by the water vapour ${ }^{19}$ $\left(\left(\mathrm{P}_{b}[\mathrm{mmHg}]-47\right) \cdot\right.$ test gas concentration $\left.[\mathrm{vol} \%] / 100\right)$. With mainstream devices a flushing period of more than one hour before the measurement with saturated air appeared to be sufficient as no difference in reading or water drop accumulation occurred in the measuring cuvette. Respiratory cycles were simulated for the sidestream devices as described above. The mainstream devices were cycled by flushing with warmed and fully saturated air at $35 \pm 2{ }^{\circ} \mathrm{C}$ (measured at $T_{4}$ in Figure 1) supplied by
}

an extra humidifier (Puritan-Bennett Ltd, Overland Park/USA), thus avoiding temperature and humidity drops during cycling. At the end of the measurements with wet gases, humidity and temperature were measured at the exhaust outlet of the sidestream devices.

\section{Temperature and moisture measurements of the breathing and sampling system in clinical conditions} To obtain temperature and moisture data found in the airways during clinical situations, temperature and humidity were measured in 15 ASA I and II patients scheduled for operations of two or more hours under general anaesthesia. Measurements were made at the patient side of the humidity and moisture exchanger (artificial nose), at the sampling site of the Y-piece and at the end of the sampling tube (entering the water trap of the monitors). The probe of the instrument was built into a modified non-metallic Y-piece creating a dead space of $<10$ $\mathrm{ml}$. The probe was removed every $15 \mathrm{~min}$ for the measurement of the two variables in the operating room.

\section{Accuracy of alarm activation}

The accuracy of alarm activation was investigated by selecting two frequently used alarm set points, 50 and 25 $\mathrm{mmHg}$. The alarms were activated by varying the $\mathrm{CO}_{2}$ concentrations delivered to the sensors using dry test gases diluted with $\mathrm{N}_{2}$. The resulting $\mathrm{CO}_{2}$ readings were compared with the alarm set points and the display readings of the Servomex which was used as a reference device. Each monitor was prepared for the alarm test by setting the high and the low alarm limit at 50 and $25 \mathrm{mmHg}$ respectively. The generated $\mathrm{CO}_{2}$ concentrations were first roughly adjusted resulting in a reading of $10 \%$ above the low and $10 \%$ below the high alarm limit. The $\mathrm{CO}_{2}$ concentrations were then increased or decreased stepwise (about $0.5 \mathrm{mmHg}$ ) until the alarms were activated. The measurements of the alarm limits were performed four times alternating high and low levels.

\section{Effect of nitrous oxide and oxygen}

The influence of the carrier gases, $\mathrm{N}_{2} \mathrm{O}$ and $\mathrm{O}_{2}$, was tested with test gases premixed according to the DIS: 5 vol\% $\mathrm{CO}_{2}, 80$ vol\% $\mathrm{N}_{2} \mathrm{O}$, balance $\mathrm{N}_{2}$ and 5 vol $\% \mathrm{CO}_{2}$, balance $\mathrm{O}_{2}$, both with an absolute error of $\leq 0.5 \mathrm{vol} \%$. The monitors which required a manual setting of the corresponding interfering gas correction were prepared accordingly each time before exposure to the test gases. In the devices where the $\mathrm{PETCO}_{2}$ values are corrected automatically (based on the inspiratory $\mathrm{O}_{2}$ and $\mathrm{N}_{2} \mathrm{O}$ values) proper correction was achieved after an apnoea time $(>20 \mathrm{sec})$ allowing the analysers to shift to the expiratory values. According to the DIS, the tested monitors should be exposed to the interfering test gases for two hours before 
TABLE I Monitors not fulfilling the DIS accuracy test of the $\mathrm{CO}_{2}$ display (DIS) or the manufacturers' information (MI) about accuracy for dry (d) and wet (w) gases

\begin{tabular}{|c|c|c|c|}
\hline & $\begin{array}{l}2.5 \mathrm{vol} \% \\
\mathrm{CO}_{2}\end{array}$ & $\begin{array}{l}5.0 \text { vol\% } \\
\mathrm{CO}_{2}\end{array}$ & $\begin{array}{l}10.0 \text { vol\% } \\
\mathrm{CO}_{2}\end{array}$ \\
\hline \multicolumn{4}{|l|}{ Mainstream monitors } \\
\hline Capnogard & & MI: d & MI: d \\
\hline \multicolumn{4}{|c|}{$\begin{array}{l}\text { S1-type monitors } \\
\text { (respiratory cycles not demanded) }\end{array}$} \\
\hline $\begin{array}{l}\text { Bruel \& Kjaer } 1304 \\
\text { Capnomac II }\end{array}$ & MI: d & MI: d & $\begin{array}{l}\text { MI: d,w } \\
\text { MI: d, w }\end{array}$ \\
\hline MGA-AS & MI: d, w & MI: d, w : DIS: w & MI: d, w : DIS: w \\
\hline \multicolumn{4}{|c|}{$\begin{array}{l}\text { S2-type monitors } \\
\text { (respiratory cycles demanded) }\end{array}$} \\
\hline $\begin{array}{l}\text { BCI } 9000 \\
\text { BCI } 9100\end{array}$ & $\begin{array}{l}\text { MI: w } \\
\text { MI: w }\end{array}$ & $\begin{array}{l}\text { MI: w } \\
\text { MI: w }\end{array}$ & \\
\hline PM 80-20 & & MI: w & MI: w \\
\hline
\end{tabular}

the measurements. In order to determine whether this long exposure had any influence on the results, we randomly chose five of the whole group of monitors and tested them strictly according to the proposal. The results of this subgroup and those given by full testing were then compared (mean of differences).

\section{Results}

During all measurements the gas and ambient temperature remained at $22 \pm 1.0^{\circ} \mathrm{C}$; ambient pressure was in the range of $717.75 \pm 5.63 \mathrm{mmHg}$. The reference monitor Servomex 2500 showed differences of $\leq 0.85 \%$ rel with all test gases.

\section{Accuracy with dry test gases}

All tested analysers complied with the accuracy required in the DIS for dry gases, balance $\mathrm{N}_{2}$ and air, over the full scale, but not all monitors fulfilled the manufacturers' information concerning accuracy (Table I).

All monitors showed the greatest absolute bias with 10 vol $\% \mathrm{CO}_{2}$. The difference $\left(\mathrm{N}_{2}\right.$-air) of mean absolute bias (MAB) showed that all analysers were slightly $(\leq 1$ $\mathrm{mmHg}$ ) more accurate with test gases containing air than $\mathrm{N}_{2}$, except Poet II, MGA-AS and Passport. Best accuracy (MAB) was achieved in Hellige ETC (M-type 0.28 $\mathrm{mmHg} \pm 0.27$ ), Multinex (S1-type $0.25 \mathrm{mmHg} \pm 0.26$ ) and Poet II (S2-type $0.86 \mathrm{mmHg} \pm 1.21$ ). The average of MAB (balance air and $\mathrm{N}_{2}$ ) revealed that M-type monitors are slightly more accurate $(0.7 \mathrm{mmHg}$ ) than the $\mathrm{S1}$ or S2-type analysers $(1.4 \mathrm{mmHg}$ ); there is, however, no statistical significance (see Figures $2 \mathrm{a}$ to $4 \mathrm{a}$ ).

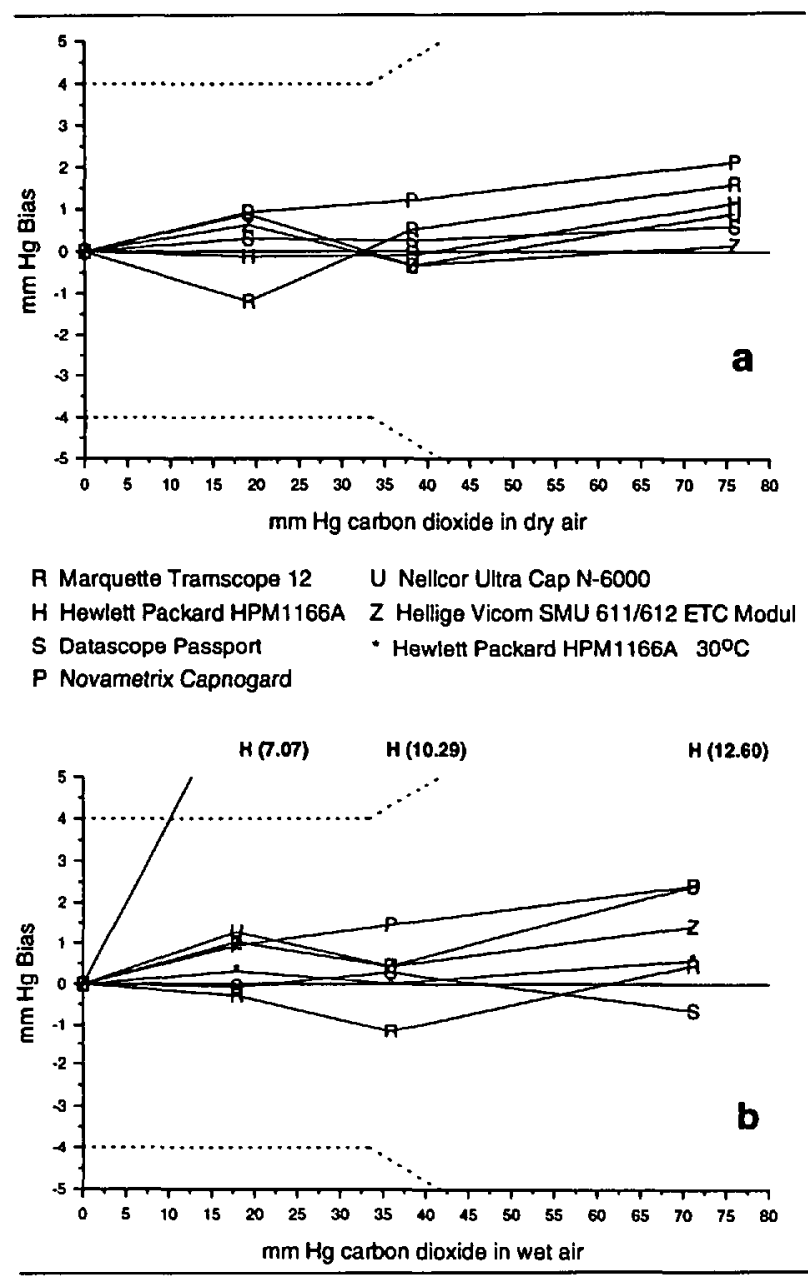

FIGURE 2 Bias (mean of four measurements) of the monitors display values to the (a) dry and (b) wet test gas values, balance air, in mainstream $\mathrm{CO}_{2}$ analysers. The dotted lines denote the DIS limits. Standard deviations for (a) $\leq \pm 0.61 \mathrm{mmHg}$, (b) $\leq \pm 0.62 \mathrm{mmHg}$, except $\mathrm{H}: \leq \pm 1.43 \mathrm{mmHg}$.

\section{Interference by water vapour}

The temperatures in the sampling unit remained stable during the testing period $\left(\mathrm{T}_{1}=45.7 \pm 0.52^{\circ} \mathrm{C} ; \mathrm{T}_{2}=\right.$ $\left.42.5 \pm 0.55 ; T_{3}, T_{4}=37.2 \pm 0.27\right)$.

\section{Liquid water interference}

Water condensation in the sample lines was considerable, almost completely filling the liquid trap after 10-12 hr of use under wet conditions. If no pooled water was aspirated, occlusion of the lines did not occur in any of the sidestream monitors. Water vapour condensed in the adult airway adapter (HP 14365A) of the HP M1166A resulting in a falsely high $\mathrm{CO}_{2}$ reading and complete failure. However, repeating the wet gas testing by heating the saturated test gases to $30 \pm 2^{\circ} \mathrm{C}$ only (comparable conditions at end of tube) changed the results of the $\mathrm{CO}_{2}$ readings for this particular monitor dramatically (Figure $2 b$ ). 


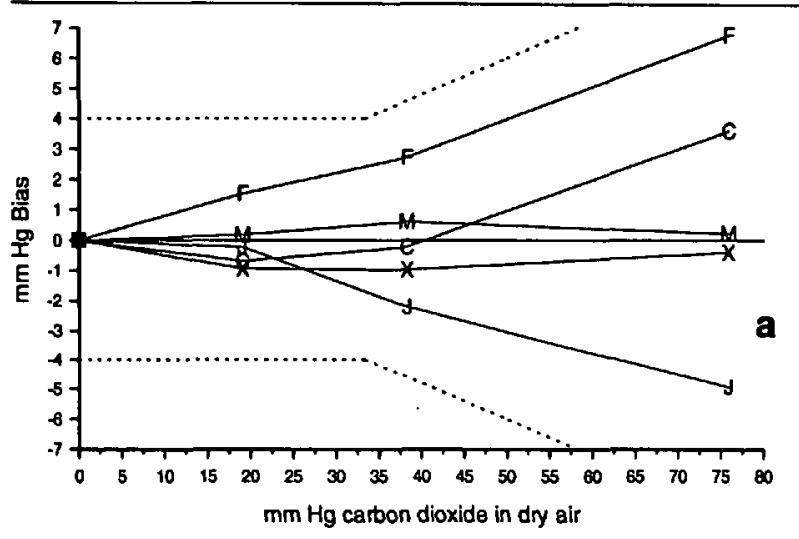
$\begin{array}{ll}\text { C Datex Capnomac II } & \text { J Brüel \& Kjaer } 1304 \\ \text { X Ohmeda OxiCap } & \text { M Datascope Multinex }\end{array}$

F Marquetie MGA-AS

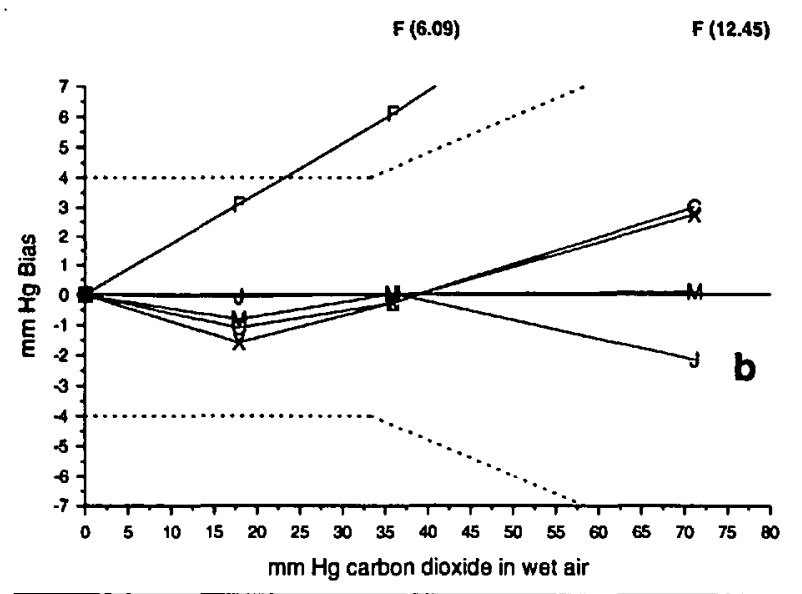

FIGURE 3 Bias (mean of four measurements) of the monitors display values to the (a) dry and (b) wet test gas values, balance air, in $\mathrm{S} 1$-type $\mathrm{CO}_{2}$ analysers (respiratory cycles not demanded). The dotted lines denote the DIS limits. Standard deviations for (a) $\leq \pm 0.54$ $\mathrm{mmHg}$, (b) $\leq \pm 0.60 \mathrm{mmHg}$, except $\mathrm{F}: \leq \pm 0.98 \mathrm{mmHg}$.

\section{Accuracy for saturated gas measurements}

The sidestream monitors: BCI 9000, BCI 9100, PM 8020 showed great biases and reached the maximal tolerated deviations as proposed by the DIS especially with 10 vol\% $\mathrm{CO}_{2}$ (Figure $4 \mathrm{~b}$ ). The MGA-AS even exceeded the limits with 5 and 10 vol\% $\mathrm{CO}_{2}$ (Figure 3b, Table I). The accuracy of the mainstream monitors was well within the limits of the DIS and Passport showed the least MAB $(0.25 \mathrm{mmHg} \pm 0.29)$ of all tested monitors. The greatest bias was found in the Capnogard: $4.2 \mathrm{mmHg}$ at $10 \mathrm{vol} \%$ $\mathrm{CO}_{2}$, balance $\mathrm{N}_{2}$. The difference $\left(\mathrm{N}_{2}\right.$-air) of MAB showed that accuracy was slightly better $(\leq 1 \mathrm{mmHg})$ with test gases containing air, especially at full range.

The direct effect of humidity on the readings could be demonstrated in all the monitors except in the Ser-

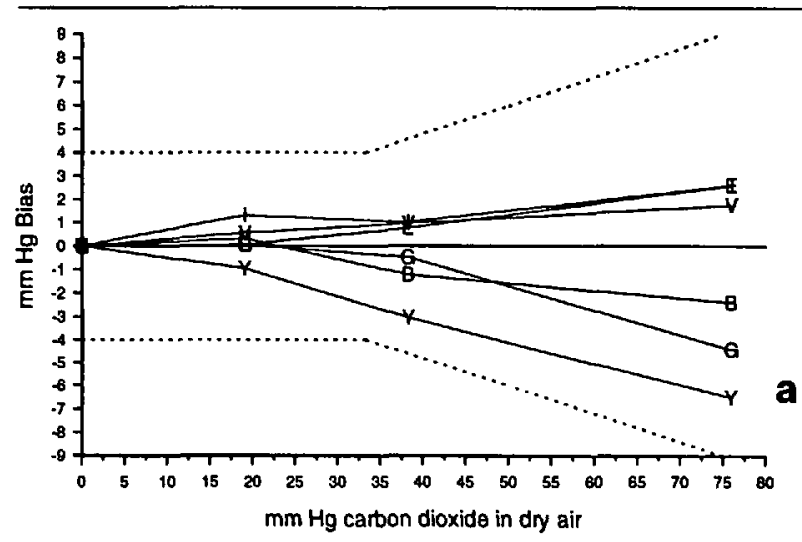
I Biochem BCl 9000
B Bruker BCl 9100
Y Hellige Vicom A-Gas
G Dräger Capnodig
$\checkmark$ Dräger PM8020
E CriticarePoet III

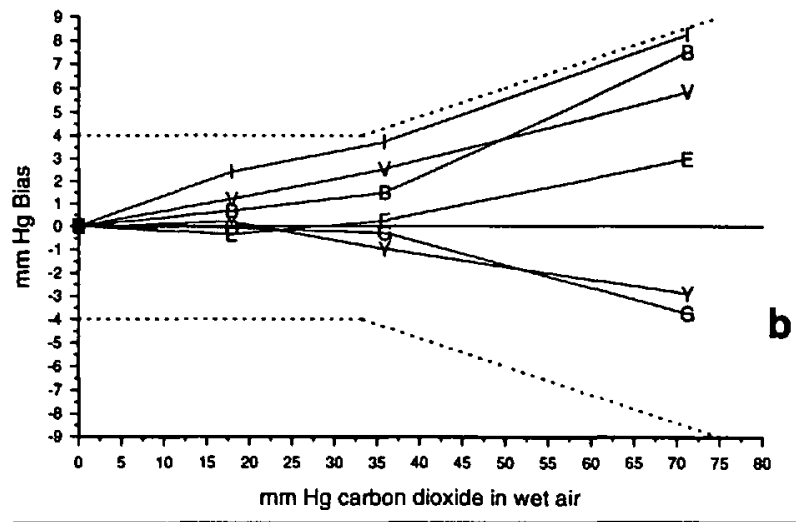

FIGURE 4 Bias (mean of four measurements) of the monitors display values to the (a) dry and (b) wet test gas values, balance air, in S2-type $\mathrm{CO}_{2}$ analysers (respiratory cycles demanded). The dotted lines denote the DIS limits. Standard deviations for (a) $\leq \pm 0.53 \mathrm{mmHg}$, (b) $\leq \pm 0.60 \mathrm{mmHg}$.

vomex. The readings with humid gases were generally slightly lower showing a dry/wet ratio of $>1$, except in the two monitors, Brüel \& Kjaer 1304 and BCI 9000 , where the ratio was $<1$ (Table II). The table also shows to what extent the gas samples are dried in relation to the laboratory environment.

\section{Temperature and moisture measurements of the} breathing and sampling system in clinical conditions At fresh gas flows of $1 \mathrm{~L} \cdot \mathrm{min}^{-1}$ the airway gases were mostly saturated. When the fresh gas flow rate was kept at $3 \mathrm{~L} \cdot \mathrm{min}^{-1}$ the moisture reached lowest values after four hours of ventilation: $60.4 \%$ relative humidity at the mainstream (Y-piece) and $53 \%$ at the inlet of the sidestream monitor (Table III). 
TABLE II Temperature and humidity of the test gases measured behind the monitor sensor units and of the laboratory environment. The dry/wet ratio shows the water vapour interference

\begin{tabular}{|c|c|c|c|c|c|}
\hline & \multicolumn{2}{|c|}{ Sample exhaust at the monitor outlet } & \multicolumn{2}{|c|}{ Laboratory environment } & \multirow{2}{*}{$\begin{array}{l}\text { Mean dry/wet ratio of the } \\
\text { mean } \mathrm{PETCO} \mathrm{O}_{2} \text { reading over } \\
\text { the full scale corrected to } \\
760 \mathrm{~mm} \mathrm{Hg}\end{array}$} \\
\hline & $\operatorname{Temp}\left({ }^{\circ} \mathrm{C}\right)$ & Humidity (\% rel) & $\operatorname{Temp}\left({ }^{\circ} \mathrm{C}\right)$ & Humidity (\% rel) & \\
\hline \multicolumn{6}{|c|}{$\begin{array}{l}\text { SI-type monitors } \\
\text { (respiratory cycles not demanded) }\end{array}$} \\
\hline Brtuel \& Kjaer 1304 & 23.0 & 43.0 & 22.0 & 50.2 & 0.982 \\
\hline Capnomac II & 25.3 & 82.0 & 24.5 & 34.0 & 1.052 \\
\hline MGA-AS & 23.5 & 98.6 & 21.0 & 38.0 & 1.012 \\
\hline Multinex & 24.2 & 94.6 & 22.0 & 50.0 & 1.073 \\
\hline OxiCap & 24.5 & 48.5 & 23.5 & 34.0 & 1.038 \\
\hline Servomex* & 23.5 & 48.0 & 22.0 & 49.4 & 1.000 \\
\hline \multicolumn{6}{|c|}{$\begin{array}{l}\text { S2-type monitors } \\
\text { (respiratory cycles demanded) }\end{array}$} \\
\hline $\mathrm{BCI} 9000$ & 24.0 & 52.3 & 23.2 & 34.0 & 0.968 \\
\hline BCI 9100 & 25.2 & 37.5 & 24.6 & 34.0 & 1.005 \\
\hline Capnodig & 25.0 & 91.0 & 24.2 & 34.0 & 1.023 \\
\hline PM 8020 & 21.5 & 50.0 & 21.0 & 53.0 & 1.016 \\
\hline Poet II & 25.5 & 83.5 & 24.6 & 34.0 & 1.044 \\
\hline \multirow[t]{3}{*}{ Vicom A-GAS } & 23.3 & 44.0 & 22.0 & 46.0 & 1.016 \\
\hline & \multicolumn{2}{|c|}{ Test gases passing the sensor cuvettes } & \multicolumn{2}{|c|}{ Laboratory environment } & $\begin{array}{l}\text { Mean dry/wet ratio of the } \\
\text { mean } \mathrm{PETCO}_{2} \text { reading over }\end{array}$ \\
\hline & $\operatorname{Temp}\left({ }^{\circ} \mathrm{C}\right)$ & Humidity (\% rel) & $\operatorname{Temp}\left({ }^{\circ} \mathrm{C}\right)$ & Humidity (\% rel) & $760 \mathrm{~mm} \mathrm{Hg}$ \\
\hline \multicolumn{6}{|l|}{ Mainstream monitors } \\
\hline Capnogand & $37.0 \pm 2$ & 100.0 & 21.3 & 36.0 & 1.081 \\
\hline \multirow[t]{2}{*}{ HP M1166A } & $37.0 \pm 2$ & 100.0 & 23.0 & 37.0 & 0.866 \\
\hline & $30.0 \pm 1$ & 100.0 & 22.0 & 41.5 & 1.060 \\
\hline Passport & $37.0 \pm 2$ & 100.0 & 22.5 & 36.5 & 1.064 \\
\hline Tramscopel2 & $37.0 \pm 2$ & 100.0 & 23.0 & 36.0 & 1.075 \\
\hline Ultracap & $37.0 \pm 2$ & 100.0 & 23.0 & 38.6 & 1.089 \\
\hline Vicom ETC & $37.0 \pm 2$ & 100.0 & 22.0 & 37.6 & 1.081 \\
\hline
\end{tabular}

*No intrinsic drying system, external Nafion tube used.

\section{Accuracy of alarm activation}

All tested analysers complied with the accuracy of alarm activation proposed by the DIS ( $\leq 0.2$ vol\%), except the Capnodig where the bias reached $1.75 \mathrm{mmHg}$ for the upper alarm limit. The average (low and high) of MAB $(\mathrm{mmHg})$ was in M-type: $0.42 \pm 0.49$, S1-type: $0.28 \pm$ 0.36 and S2-type: $0.52 \pm 0.57$. The difference between the $\mathrm{CO}_{2}$ readings of the Servomex and those of the monitors at alarm activation was $\leq 6 \mathrm{mmHg}$ and well within the accuracy of $\mathrm{CO}_{2}$ readings proposed by the DIS. Alarm activation of the non-clinical $\mathrm{CO}_{2}$ analyser, the Servomex, was not tested.

\section{Effect of nitrous oxide and oxygen}

The $\mathrm{CO}_{2}$ readings with the interfering gases $\mathrm{O}_{2}$ and $\mathrm{N}_{2} \mathrm{O}$ were well within the limits stated in the DIS $(\leq 12 \%)$ in all tested monitors. Measuring the effect of oxygen, the best accuracy was found in the Capnodig, the mean difference being $0.00 \mathrm{mmHg}$. The greatest difference was found in the $\mathrm{BCI} 9100(-3.49 \mathrm{mmHg})$. For $\mathrm{N}_{2} \mathrm{O}$, again, the Capnodig was found to have the smallest difference $(-0.20 \mathrm{mmHg})$. The greatest deviation was found in the MGA-AS (3.60 $\mathrm{mmHg}$ ), the Vicom A-GAS (-3.40 $\mathrm{mmHg}$ ) and the Tramscope $12(3.39 \mathrm{mmHg}$ ) (see Figure 5). The average of MAB showed that M-type analysers are less disturbed by $\mathrm{O}_{2}(0.81 \mathrm{mmHg} \pm 0.52)$ than S1$(1.30 \mathrm{mmHg} \pm 1.05)$ and S2-type $(1.98 \mathrm{mmHg} \pm 1.30)$ monitors and $\mathrm{N}_{2} \mathrm{O}$ had a higher effect in all monitors (but equal in all types: $1.74 \mathrm{mmHg} \pm 1.22$ ). A twohour period of continuous exposure to the test gases before the measurements had no influence (difference 0.00 $\mathrm{mmHg}$ ) on the results and could therefore be omitted. 
TABLE III Temperature and humidity measured in clinical conditions in 15 patients (SD = standard deviation)

\begin{tabular}{|c|c|c|c|c|}
\hline Temperature $\left({ }^{\circ} \mathrm{C}\right)$ & $\operatorname{Max}$ & Min & Mean & $S D$ \\
\hline Operation room & 22.6 & 20.9 & 21.2 & 1.1 \\
\hline Patient (rectal) & 38.4 & 35.2 & 36.3 & 0.9 \\
\hline Tube connection & 31.1 & 27.3 & 29.9 & 1.4 \\
\hline \multicolumn{5}{|l|}{ Y-piece at sample connection } \\
\hline $\begin{array}{l}\text { End of sample tube } \\
\text { (monitor inlet) }\end{array}$ & 25.9 & 21.7 & 23.3 & 1.3 \\
\hline \multicolumn{5}{|l|}{ Humidity (\% rel) } \\
\hline Operating room & 45.7 & 33.2 & 40.2 & 5.4 \\
\hline Tube connection & 100 & 93.7 & 98.9 & 2.6 \\
\hline \multicolumn{4}{|l|}{ Y-piece at sample site } & 19.8 \\
\hline $\begin{array}{l}\text { End of sample tube } \\
\text { (monitor inlet) }\end{array}$ & 100 & 53.0 & 83.5 & 15.5 \\
\hline \multicolumn{5}{|l|}{ Other parameters } \\
\hline Fresh gas flow $\left(L \cdot \min ^{-1}\right)$ & 3.0 & 1.0 & 2.2 & 0.8 \\
\hline Sample rate $\left(\mathrm{ml} \cdot \mathrm{min}^{-1}\right)$ & 200 & 200 & 200 & 0.0 \\
\hline Sample tube length $(\mathrm{cm})$ & 300 & 180 & 250.8 & 38.0 \\
\hline $\begin{array}{l}\text { Time between intubation and } \\
\text { end of measurement (min) }\end{array}$ & 345 & 50 & 120.8 & 77.1 \\
\hline
\end{tabular}

\section{Discussion}

To test gas analysers for accuracy, either precisely premixed test gases or an established reference method for gas analysis like mass spectrometry, refractometry, ${ }^{20}$ chromatography and probably other methods are needed. Since premixed gases are expensive, an accurate gas analyser to test and calibrate clinical gas monitors would be of advantage. The Servomex 2500 is a single-beam multiwavelength infrared $\mathrm{CO}_{2}$ analyser designed for industrial purposes. This instrument was used as a reference in this study because it fulfilled the manufacturer's accuracy claims (Appendix, Table VI) and its accuracy was almost comparable with those of the test gases used in this study. Although the accuracy limits proposed by the DIS are more tolerant than those used by the manufacturers (Table I) they satisfy clinical requirements entirely. The manufacturers' information on the accuracy for the Capnomac II, i.e., error $<1.5 \mathrm{mmHg}$ over the full scale and on the nonlinear error of the Briel \& Kjaer 1304 of $2 \%$ relative are too optimistic. However, at clinical $\mathrm{CO}_{2}$ concentrations the Capnomac II complied with the strictest limits set by the manufacturer whereas the Brüel \& Kjaer 1304 complied only at 10 vol\% $\mathrm{CO}_{2}$ wet.

\section{Accuracy with dry test gas}

The DIS accepts a $\mathrm{CO}_{2}$ reading of $\pm 12 \%$ relative to the actual test gas value or $\pm 4 \mathrm{mmHg}$, whichever is greater over the full range of capnometer readings ( 2.5

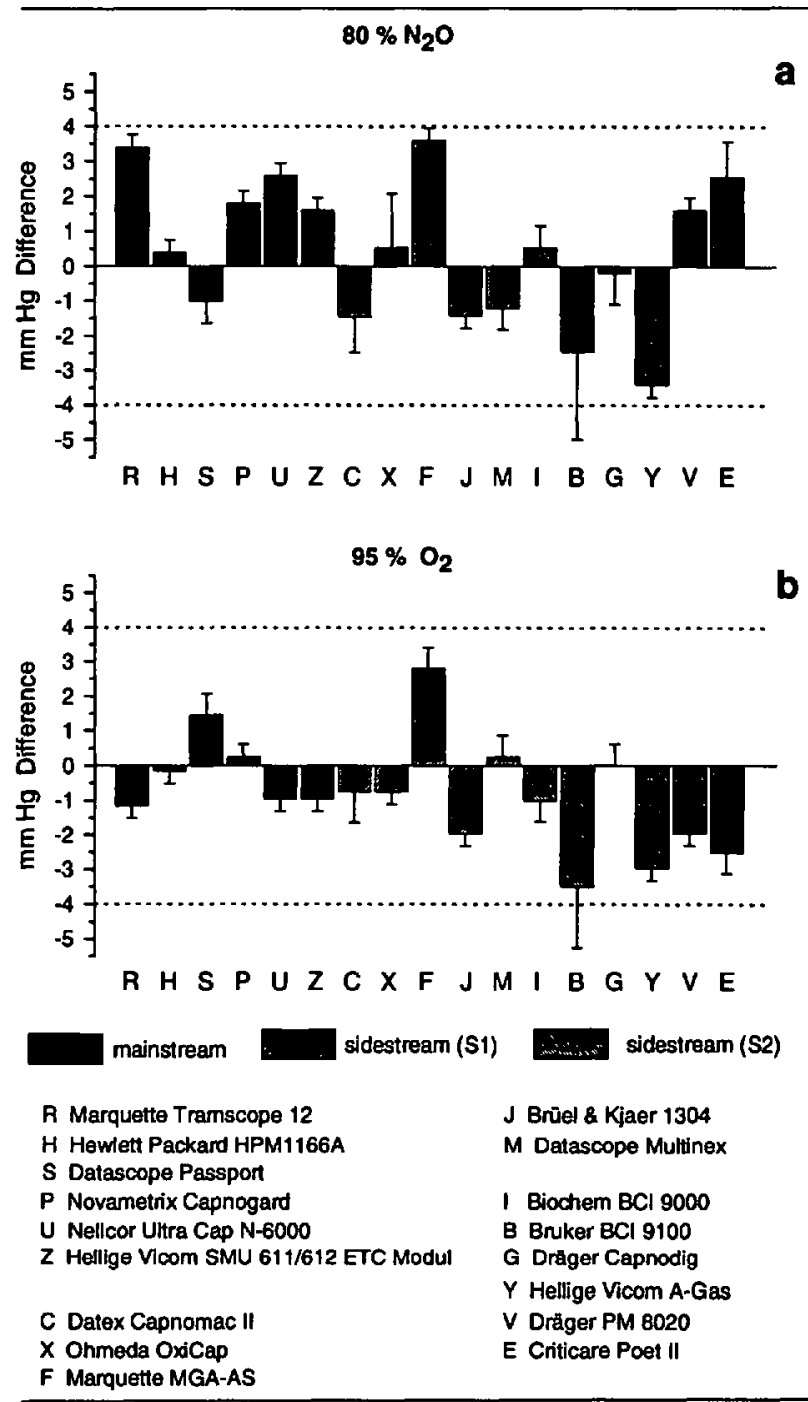

FIGURE 5 Effect of interfering dry gas mixtures on $\mathrm{CO}_{2}$ reading: (a) 5 vol\% $\mathrm{CO}_{2} 80$ vol\% $\mathrm{N}_{2} \mathrm{O}$ balance $\mathrm{N}_{2}$, (b) 5 vol\% $\mathrm{CO}_{2}, 95$ vol\% $\mathrm{O}_{2}$. The dotted lines denote the DIS limits.

vol\% $\mathrm{CO}_{2}: 19 \pm 4 \mathrm{mmHg}, 5$ vol\%: $38 \pm 4.56 \mathrm{mmHg}$, 10 vol\% $\mathrm{CO}_{2}: 76 \pm 9.12 \mathrm{mmHg}$ ). Bias was smaller with test gases containing air than those containing $\mathrm{N}_{2}$. As in clinical conditions $\mathrm{O}_{2}$ is always present, test gases containing $\mathrm{O}_{2}$ (air) are therefore more realistic than those with $\mathrm{N}_{2}$ as balance. We have therefore omitted the test results we obtained with $\mathrm{N}_{2}$.

\section{Temperature and moisture measurements of the breathing and sampling system}

When using a low-flow technique, inspired gas may be almost completely saturated in contrast to when the semiopen Mapelson or Bain systems are used (Table III). ${ }^{21,22}$ The monitors are thus exposed to gases of highly variable humidity. The manufacturers of the mainstream devices 
assume the gases to be water saturated at $28-33^{\circ} \mathrm{C}$. Many sidestream sensor units are provided with drying systems (Nafion tubing) equilibrating water vapour pressure to ambient conditions (Appendix, Table IV). Others do not dry the sampling gases at all (see sample exhaust, Table II). Reading errors of the true $\mathrm{PCO}_{2}$ resulting from the moisture present in the sample tubings have been calculated in previous studies. ${ }^{16,19}$ They were in the magnitude of $0.5 \mathrm{mmHg}$ when the gas had been dried and of $1 \mathrm{mmHg}$, if not. The sensors inserted in the mainstream at the tube connection are exposed to an average water vapour pressure of $29 \mathrm{mmHg}$ (temperature = $30^{\circ} \mathrm{C}$; relative humidity $=90 \%$; Table III), resulting in a difference to the lung value of $0.9 \mathrm{mmHg}$ at 5 vol\% $\mathrm{CO}_{2}$ and $100 \%$ water vapour saturation in the lungs $\left(0.05 \cdot\left(\mathrm{P}_{\mathrm{b}}-29\right)-0.05 \cdot\left(\mathrm{P}_{\mathrm{b}}-47\right)=0.9\right)$. In previous evaluations of the monitors Bruiel \& Kjaer 1304 and the Datex Capnomac by McPeak et al., water vapour seemed to have no effect on the gas measurements. ${ }^{23,24}$

\section{Interference by water vapour}

The water vapour has three effects on the readings: dilution of the $\mathrm{CO}_{2}$, increase of the readings by the phenomenon called "collision broadening" and absorption of some of the bands of infrared light used to measure $\mathrm{CO}_{2}$. Independent of the physical effect of the water vapour on the $\mathrm{CO}_{2}$ measurement, the water vapour pressure should be taken into account by the instruments (in clinical conditions: $\mathrm{FCO}_{2} \times(\mathrm{Pb}-47)$ ) if a true ("deep lung") value for $\mathrm{PCO}_{2}$ of the patient sample is to be expected on the display. If this correction is present, the reported values are expressed at body temperature and pressure saturated (BTPS). Without a water vapour correction the values for $\mathrm{PCO}_{2}$ are reported at ambient temperature and pressure dry (ATPD) (Appendix, Tables IV and V). The error in reporting at ATPD when it should be reported at BTPS is $2.35 \mathrm{mmHg}$ at $5 \mathrm{vol} \% \mathrm{CO}_{2}$ and $4.7 \mathrm{mmHg}$ at $10 \mathrm{vol} \% \mathrm{CO}_{2}$. To make sure that the $\mathrm{CO}_{2}$ monitor in use reports a correct $\mathrm{PCO}_{2}$ value, Severinghaus describes several methods to perform empirical calibrations. ${ }^{19}$

Selecting $\mathrm{mmHg}$, the wet measuring mode was automatically selected in the monitors with a water vapour compensation allowing for the $\mathrm{PCO}_{2}$ readings at BTPS. The operators manuals of the Briiel \& Kjaer 1304, the Ultra Cap N-6000 and the Vicom A-GAS declare that if vol\% is selected the displayed value is reported at ATPD. This dry measuring mode is not selectable in the HP M1166A. If $\mathrm{PETCO}_{2}$ values were converted to BTPS values and displayed accordingly, a comparison between arterial and mixed venous blood values would be possible. ${ }^{25}$ Severinghaus therefore strongly recommended that respiratory $\mathrm{PCO}_{2}$ analysers report their results corrected for water vapour pressure. ${ }^{19}$
During the saturated gas testing (at $37^{\circ} \mathrm{C}$ ), the water vapour did condense in the windows of the cuvette of the HP M1166A. However, when decreasing the saturated test gas temperature to $30 \pm 2^{\circ} \mathrm{C}$ the results were within the DIS limits and even showed the least MAB $(0.23 \mathrm{mmHg} \pm 0.27)$ of all tested monitors (Figure $2 \mathrm{~b}$ ). The motor and filter of the $\mathrm{CO}_{2}$-transducer (HP 14360A) is heated to $41.7^{\circ} \mathrm{C}$ (manufacturers' specifications), giving the window and the adapter a temperature of about $33^{\circ} \mathrm{C}$, which seems to be high enough to avoid condensation during clinical conditions where temperatures are rarely above $30^{\circ} \mathrm{C}$ at the tube connection (Table III). This is the only mainstream sensor which is made of metallic material heated to $33^{\circ} \mathrm{C}$, whereas all the other mainstream sensors are non-metallic and are heated to $\geq 42^{\circ} \mathrm{C}$. Since the metal airway adapter loses temperature faster than a plastic airway adapter, Hewlett Packard developed a new plastic airway adapter (HP M1465A) and $\mathrm{CO}_{2-}$ transducer (HP M1460A). This adapter has been available since September 1994 and has no more condensation problems, as we found when testing it during the revision phase of this manuscript.

\section{Effect of $\mathrm{N}_{2} \mathrm{O}$ and $\mathrm{O}_{2}$}

In spite of the unusually high levels of the interfering gases, 95 vol\% $\mathrm{O}_{2}$ and 80 vol\% $\mathrm{N}_{2} \mathrm{O}$, the monitors fulfilled the accuracy proposals for $5 \mathrm{vol} \% \mathrm{CO}_{2}$ (medium range) most satisfactorily. The Capnodig monitor was least influenced by the interfering gases. According to the manufacturer, the sampling gas is radiated from a selective IR source, a plasma radiator needing no spectral filters. This monitor does not have an incorporated correction software. In the devices, which display the interfering gases (Appendix, Tables IV and V), the $\mathrm{CO}_{2}$ values are automatically corrected based on the inspiratory values. Since respiratory cycles are simulated with air in this study, proper correction was achieved after an apnoea time allowing the analyser to shift to the expiratory values. There is no $\mathrm{O}_{2}$ cell in the Poet II (model 602-1), BCI 9100 and PM 8020, thus correction did not take place. Although $\mathrm{O}_{2}$ does not absorb IR radiation, $\mathrm{CO}_{2}$ readings are affected by collision-broadening altering the readings by up to $-2.5 \mathrm{mmHg}$, depending on $\mathrm{O}_{2}$ concentrations. ${ }^{16}$ The HP M1166A was the mainstream monitor which allowed the simultaneous use of the $\mathrm{O}_{2}$ module to obtain an automatic correction with an error of $< \pm 1 \%$ according to the manufacturer.

With nitrous oxide the greatest deviations were observed in the Tramscope 12 and in the MGA-AS. Nitrous oxide strongly influences $\mathrm{PCO}_{2}$ measurements by direct influence and collision-broadening altering the readings by up to $6.5 \mathrm{mmHg}$. Correction factors for the presence of commonly used $\mathrm{N}_{2} \mathrm{O}$ concentrations have been incor- 
porated in the monitors software, ${ }^{12,26,27}$ although errors might be mostly reduced by calibrating the instruments with a gas mixture containing $\mathrm{N}_{2} \mathrm{O} .^{14,27,28}$ Several capnometers are calibrated for low $\mathrm{O}_{2}$ compensation, assuming a reference state of $0 \mathrm{vol} \% \mathrm{~N}_{2} \mathrm{O}$ and $20 \mathrm{vol} \% \mathrm{O}_{2}$ (air), even though the user's calibration is carried out with $\mathrm{CO}_{2}$ only (Ultra Cap N-6000). We do not think that clinical monitor testing should be done with $\mathrm{O}_{2}$-free gases.

\section{Accuracy of alarm activation}

The suggested procedure in the DIS for the accuracy of the alarm limit ("... for each $\mathrm{CO}_{2}$ reading, adjust the alarm set point so that the alarm is deactivated. Incrementally adjust the alarm set point until the alarm is activated and record ...") is not feasible since in some monitors the alarm can only be set in steps of $5 \mathrm{mmHg}$ whereas in others respiratory cycles have to be registered. With the technique used in this study it is possible to read the difference between the alarm set point and the reading on the display when the alarm is activated. We believe that varying the level of $\mathrm{CO}_{2}$ until the alarm is activated produces a better simulation of the clinical reality than varying the alarm set point. The DIS does not ask for a minimal accuracy between the $\mathrm{CO}_{2}$ reading and a corresponding test gas for a given alarm set point nor for clinically relevant levels of humidity present in the gas, which may affect the performance. We decided not to test the accuracy of alarm activation with wet gases because changing the $\mathrm{CO}_{2}$ concentration step by step was much easier with dry gases. In a few monitors the alarm is activated as soon as the displayed $\mathrm{CO}_{2}$ value equals the set alarm limit (Passport, BCI 9000, BCI 9100, MGA-AS) whereas in the others the displayed value must exceed the limit by $0.5 \mathrm{mmHg}$ (displayed only in the Briel \& Kjaer 1304) or by $1.0 \mathrm{mmHg}$ (HP, Poet II, Ultracap, PM 8020).

\section{Conclusion}

In $\mathrm{CO}_{2}$ readings (dry, wet gas and effect of $\mathrm{N}_{2} \mathrm{O}$ and $\mathrm{O}_{2}$ ) the accuracy (average of MAB) was better in Mtype monitors than in S1- or S2-type analysers. Accuracy of alarm activation showed less bias in S1- than in Mor S2-type monitors. But in none of these comparisons could a statistical (or clinical) difference be detected and all tested analysers were found to be safe for clinical use, except those failing DIS limits. Most manufacturers work within stricter limits than those stated in the DIS.

\section{Acknowledgements}

We thank the education administration of the Kt. Berr. for the financial support of this work, Mrs. Margrit Leggoe for her help in the preparation of the manuscript and Mr. M. Mosimann for repeated measurements on some devices.

\section{References}

1 Tinker JH, Dull DL, Caplan RA, Ward RJ, Cheney FW. Role of monitoring devices in prevention of anesthetic mishaps: a closed claims analysis. Anesthesiology 1989; 71 : 541-6.

2 Takki S, Aromaa U, Kauste A. The validity and usefulness of the end-tidal $\mathrm{pCO}_{2}$ during anaesthesia. Ann Clin Res 1972; 4: 278-84.

3 Murray IP, Modell JH. Early detection of endotracheal tube accidents by monitoring carbon dioxide concentration in respiratory gas. Anesthesiology 1983; 59: 344-6.

4 Eichhorn JH. Prevention of intraoperative anesthesia accidents and related severe injury through safety monitoring. Anesthesiology 1989; 70: 572-7.

5 Coté CJ, Liu LMP, Szyfelbein SK, et al. Intraoperative events diagnosed by expired carbon dioxide monitoring in children. Can Anaesth Soc J 1986; 33: 315-20.

6 American Society of Anesthesiologists. Standards for basic anesthetic monitoring, 13. October 1993.

7 Block FE Jr. A carbon dioxide monitor that does not show the waveform is worthless. J Clin Monit 1988; 4: 213-4.

8 Paloheimo MPJ. A carbon dioxide monitor that does not show the waveform has value. J Clin Monit 1988; 4: 210-2.

9 Block FE Jr, McDonald JS. Sidestream versus mainstream carbon dioxide analyzers. J Clin Monit 1992; 8: 139-41.

10 From $R P$, Scamman $F L$. Ventilatory frequency influences accuracy of end-tidal $\mathrm{CO}_{2}$ measurements. Analysis of seven capnometers. Anesth Analg 1988; 67: 884-6.

11 Sasse FJ. Can we trust end-tidal carbon dioxide measurements in infants? (Editorial). J Clin Monit 1985; 1: 147-8.

12 Mogue LR, Rantala B. Capnometers. J Clin Monit 1988; 4: 115-21.

13 Bhavani-Shankar K, Moseley H, Kumar AY, Delph Y. Capnometry and anaesthesia. Can J Anaesth 1992; 6: 617-32.

14 Gravenstein JS. Monitoring of respired gases. Current Reviews in Clinical Anesthesia 1989; 10: 61-8.

15 Gravenstein JS. Gas Monitoring and Pulse Oximetry. Boston: Butterworth-Heinemann, 1990.

16 Raemer DB, Calalang $I$. Accuracy of end-tidal carbon dioxide tension analyzers. J Clin Monit 1991; 7: 195-208.

17 International Standard Organisation. \# 9918 Capnometers for use with humans - requirements. 15th February 1993.

18 International Standard Organisation, ISO 6142. Gas analysis - preparation of calibration gas mixtures - weighing methods. 1st July 1981.

19 Severinghaus JW. Water vapour calibration errors in some capnometers: respiratory conventions misunderstood by manufacturers? Anesthesiology 1989; 70: 996-8. 
20 Parbrook GD, Davis PD, Parbrook EO. Basic Physics and Measurement in Anaesthesia, 3rd ed. Boston: Butterworth-Heinemann, 1990: 257-64.

21 Kleeman PP. Klimatisierung anăsthetischer Gase durch Reduktion des Frischgasflows. In: Jantzen J-PAH, Kleemann PP (Eds.). Narkosebeatmung. Stuttgart: Schattauer 1989.

22 Bengtson JP, Bengtson A, Sonander $H$, Stenqvist $O$. Humidity of the Bain and circle systems reassessed. Anesth Analg 1989; 69: 83-9.

23 McPeak HB, Palayiwa E, Robinson GC, Sykes MK. An evaluation of the Bruel and Kjaer monitor 1304. Anaesthesia 1992; 47: 41-7.

24 McPeak HB, Palayiwa $E$, Madgwick $R$, Sykes $M K$. Evaluation of a multigas anaesthetic monitor: the Datex Capnomac. Anaesthesia 1988; 43: 1035-41.

25 Gravenstein JS. Gas Monitoring and Pulse Oximetry. Boston: Butterworth-Heinemann 1990; 19-25.

26 Bergman NA, Rackow H, Frumin MJ. The collision broadening effect of nitrous oxide upon infrared analysis of carbon dioxide during anesthesia. Anesthesiology 1958; 19: 19-26.

27 Kennell EM, Andrews RW, Wollman $H$. Correction factors for nitrous oxide in the infrared analysis of carbon dioxide. Anesthesiology 1973; 39: 441-3.

28 Sykes MK, Vickers MD, Hull CJ. Principles of Measurement and Monitoring in Anaesthesia and Intensive Care, 3rd ed. London: Blackwell Scientific Publications, 1991. 


\section{Appendix}

TABLE IV Manufacturers' specification of the tested sidestream infrared carbon dioxide analysers (auto $=$ automatically, man $=$ manually, cal $=$ calibration, sel $=$ selectable, baro $=$ barometer $)$

\begin{tabular}{|c|c|c|c|c|c|}
\hline \multirow[b]{2}{*}{ Monitoring unit } & \multicolumn{5}{|c|}{ SI-type monitors (respiratory cycles not demanded) } \\
\hline & Type 1304 & Capnomac II & $M G A-A S$ & Multinex & 4700 OxiCap \\
\hline Country of origin & Denmark & Finland & USA & USA & USA \\
\hline Manufacturer & Bruel \& Kjaer & Datex & Marquette & Datascope & Ohmeda \\
\hline $\begin{array}{l}\text { Accuracy of display in } \mathrm{mmHg} \text { or } \\
\text { otherwise stated at different scale } \\
\text { ranges according to manufacturer }\end{array}$ & $\begin{array}{l}\text { Nonlinear error } 2 \% \text { and } \\
1 \% \text { full scale } \\
\text { Zero error }<0.1 \%\end{array}$ & $\begin{array}{l}<0.2 \mathrm{vol \%} \\
<1.5 \mathrm{mmHg}\end{array}$ & $\begin{aligned} 0-40 & = \pm 1.5 \\
41-60 & = \pm 2.5 \\
61-76 & = \pm 4\end{aligned}$ & $\begin{aligned} 0-20 & = \pm 1.5 \\
20-40 & = \pm 2.0 \\
40-60 & = \pm 2.5 \\
60-76 & = \pm 3.0\end{aligned}$ & $\begin{array}{l}0-7 \%= \pm 2.2 \\
7-9 \%= \pm 5\end{array}$ \\
\hline Calibration interval & $3 \mathrm{mo}$ & $6 \mathrm{mo}$ & $6 \mathrm{mo}$ & No user cal & Weekly \\
\hline Zero calibration & Not required & Auto/man & Auto/man & Auto & Auto \\
\hline Span calibration & Cal mixture & Cal mixture & Cal mixture & No user cal & Cal mixture \\
\hline Display range and units for $\mathrm{ETCO}_{2}$ & $\begin{array}{l}0.0-10.0 \% \\
\mathrm{mmHg} / \mathrm{kPa}\end{array}$ & $\begin{array}{l}0-10 \% \\
0-76 \mathrm{mmHg}\end{array}$ & $\begin{array}{l}0-10 \%, \mathrm{kPa} \\
\mathrm{mmHg}\end{array}$ & $\begin{array}{l}0-76 \mathrm{mmHg} \\
0-9.9 \% / \mathrm{kPa}\end{array}$ & $\begin{array}{l}0-14 \% \\
\mathrm{mmHg}\end{array}$ \\
\hline Multigas analyser & Yes & Yes & Yes & Yes & No \\
\hline Insp. $\mathrm{CO}_{2}$ display & Yes & Yes & Yes & Yes & Yes \\
\hline $\begin{array}{l}\text { Barometric pressure-compensation } \\
\text { [mmHg] }\end{array}$ & $\begin{array}{l}\text { Auto } \\
540-840\end{array}$ & $\begin{array}{l}\text { Auto } \\
500-800\end{array}$ & Auto & $\begin{array}{l}\text { Sel } 760 \mathrm{~mm} \\
\text { or local baro }\end{array}$ & $\begin{array}{l}\text { Auto } \\
500-800\end{array}$ \\
\hline Compensation: $\mathrm{N}_{2} \mathrm{O}$ & Auto & Auto & Auto & Auto & Auto \\
\hline Display $\mathrm{N}_{2} \mathrm{O}$ & Yes & Yes & Yes & Yes & Yes \\
\hline Compensation: $\mathrm{O}_{2}$ & Auto & Auto & Auto & Auto & Auto \\
\hline Display $\mathrm{O}_{2}$ & Yes & Yes & Yes & Yes & Yes \\
\hline Correction for water vapour $47 \mathrm{mmHg}$ & Yes & No & No & $\begin{array}{l}\text { Sel no } \\
47 \mathrm{mmHg} \text { corr }\end{array}$ & No, error $\leq 2 \mathrm{~mm}$ \\
\hline Sample gas drying & Yes & Yes & No & No & Yes \\
\hline $\begin{array}{l}\text { Continuous digital display for } \mathrm{CO}_{2} \\
\text { (respiratory cycles not demanded) }\end{array}$ & Yes & Yes & Yes & Yes & Yes \\
\hline Sample flow $\left(\mathrm{ml} \cdot \mathrm{min}^{-1}\right)$ & 90 & 200 & $50,150,250$ & $50,100,150,200$ & 300 \\
\hline Operation temp. $\left[{ }^{\circ} \mathrm{C}\right]$ & $10-40$ & $10-35$ & $10-30$ & $10-35$ & $15-40$ \\
\hline Warm up time [min] & $1 \mathrm{~min}$ & 2 & & $15 \mathrm{~min}$ & 1.5 \\
\hline Analogue output & Optional & Yes & Optional & Yes & Yes \\
\hline
\end{tabular}

S2-type monitors (respiratory cycles demanded)

\begin{tabular}{|c|c|c|c|c|c|c|}
\hline Monitoring unit & $B C I 9000$ & $B C I 9100$ & Capnodig & $P M 8020$ & Poet II & $\begin{array}{l}\text { Vicom-sm SMU } \\
611 / 612 A-G A S\end{array}$ \\
\hline Country of origin & USA & USA & Germany & Germany & USA & Germany \\
\hline Manufacturer & Biochem & Bruker & Dräger & Dräger & Criticare & Hellige \\
\hline $\begin{array}{l}\text { Accuracy of display in } \mathrm{mmHg} \text { or } \\
\text { otherwise stated at different scale } \\
\text { ranges according to manufacturer }\end{array}$ & $0-50= \pm 2$ & $0-50= \pm 2$ & $\begin{array}{l}0-38= \pm 4 \\
38-76= \pm 10 \% \\
\text { of display }\end{array}$ & $\begin{aligned} 0-40 & = \pm 1.5 \\
40-60 & = \pm 2.5 \\
60-80 & = \pm 4.0\end{aligned}$ & \pm 2 & $\begin{array}{r}0-20= \pm 3.5 \\
21-40= \pm 3.7 \\
41-60= \pm 4.8 \\
61-80= \pm 6.7\end{array}$ \\
\hline Calibration interval & $6 \mathrm{mo}$ & $100 \mathrm{hr}$ auto & $6 \mathrm{mo}$ & $6 \mathrm{mo}$ & $6 \mathrm{mo}$ & $6 \mathrm{mo}$ \\
\hline Zero calibration & Auto & Auto/man & Auto & Auto & Auto & Auto \\
\hline Span calibration & Cal mixture & Cal tank & Cal mixture & Cal mixture & Cal mixture & Cal mixture \\
\hline Display range and units for $\mathrm{ETCO}_{2}$ & $\begin{array}{l}0-100 \\
\mathrm{mmHg}\end{array}$ & $\begin{array}{l}0-100 \\
\mathrm{mmHg}\end{array}$ & $\begin{array}{l}0-10 \%, \mathrm{kPa} \\
\mathrm{mmHg}\end{array}$ & $\begin{array}{l}0-80 \mathrm{mmHg} \\
0-9.9 \mathrm{kPa}\end{array}$ & $\begin{array}{l}0-90 \\
\mathrm{mmHg}\end{array}$ & $\begin{array}{l}0-80 \mathrm{mmHg} \\
\text { vol\% }\end{array}$ \\
\hline Multigas analyser & No & Yes & No & Yes & No & Yes \\
\hline Insp. $\mathrm{CO}_{2}$ display & Yes & Yes & No & Yes & Yes & Yes \\
\hline $\begin{array}{l}\text { Barometric pressure-compensation } \\
\text { [mmHg] }\end{array}$ & Auto & Auto & $\begin{array}{l}\text { Man } \\
600-1200\end{array}$ & Auto & $\begin{array}{l}\text { Auto } \\
0-990\end{array}$ & $\begin{array}{l}\text { Auto } \\
500-800\end{array}$ \\
\hline Compensation: $\mathrm{N}_{2} \mathrm{O}$ & Auto & Auto & No $(0-80 \%)$ & Auto & Sel & Auto \\
\hline Display $\mathrm{N}_{2} \mathrm{O}$ & Yes & Yes & No & Yes & No & Yes \\
\hline Compensation: $\mathrm{O}_{2}$ & No & No & No $(0-75 \%)$ & Auto & No & Auto \\
\hline Display $\mathrm{O}_{2}$ & No & No & No & No & No & Yes \\
\hline $\begin{array}{l}\text { Correction for water vapour } 47 \\
\mathrm{mmHg}\end{array}$ & No & No & No & No & No & Yes \\
\hline Sample gas drying & Yes & Yes & Yes & Yes & No & Yes \\
\hline $\begin{array}{l}\text { Continuous digital display for } \mathrm{CO}_{2} \\
\text { (respiratory cycles not demanded) }\end{array}$ & No & No & No & $\begin{array}{l}\text { No } \\
\text { Yes if }>5 \mathrm{mmHg} \\
\quad \text { and }>20 \mathrm{sec}\end{array}$ & No, only as meter & No \\
\hline Sample flow $\left(\mathrm{ml} \cdot \mathrm{min}^{-1}\right)$ & 140 & 140 & $\leq 150$ & 50,200 & 50,150 & 125,250 \\
\hline $\begin{array}{l}\text { Operation temp. }\left[{ }^{\circ} \mathrm{C}\right] \\
\text { Warm up time [min] }\end{array}$ & $10-40$ & $10-40$ & $\begin{array}{l}15-40 \\
3\end{array}$ & $\begin{array}{l}15-40 \\
15\end{array}$ & $\begin{array}{l}10-40 \\
3\end{array}$ & $\begin{array}{l}15-45 \\
5\end{array}$ \\
\hline Analogue output & Yes & Yes & Yes & No & Yes & No \\
\hline
\end{tabular}


TABLE V Manufacturers' specification of the tested mainstream infrared carbon dioxide analysers (auto $=$ automatically, $\operatorname{man}=\operatorname{manually,~} \mathrm{cal}=$ calibration)

\begin{tabular}{|c|c|c|c|c|c|c|}
\hline Monitoring unit-Modules & Capnogard & $\begin{array}{l}\mathrm{HP} M 1166 \mathrm{~A} \\
\mathrm{CO}_{2} \text { module } \\
(\mathrm{HP} \text { M1016A) }\end{array}$ & Passport & $\begin{array}{l}\text { Tramscope } 12 \\
\mathrm{CO}_{2} \text { module }\end{array}$ & $\begin{array}{l}\text { Ultra Cap } \\
N-6000\end{array}$ & $\begin{array}{l}\text { Vicom-sm } \\
\text { SMU } 611 / 612 \\
\text { ETC-Modul }\end{array}$ \\
\hline Country of origin & USA & Germany & USA & USA & USA & Germany \\
\hline Manufacturer & Novametrix & Hewlett Packard & Datascope & Marquette & Nellcor & Hellige \\
\hline $\begin{array}{l}\text { Accuracy of display }(\mathrm{mmHg}) \text { at } \\
\text { different scale ranges } \\
\text { according to manufacturer }\end{array}$ & $\begin{array}{l}0-40= \pm 2 \\
41-100= \pm 5 \% \\
\text { of reading }\end{array}$ & $\begin{array}{l}0-40= \pm 2.2 \\
40-100= \pm 5.5 \% \\
\text { of reading }\end{array}$ & $0-40= \pm 4$ & $\begin{array}{l} \pm 2 \text { or } \pm 5 \% \\
\text { of reading, } \\
\text { whichever is } \\
\text { greater }\end{array}$ & $\begin{array}{c}0-40= \pm 2 \\
41-99= \pm 5 \% \\
\text { of reading }\end{array}$ & $\begin{array}{c}0-39= \pm 2 \\
40-79= \pm 5 \% \\
\text { of reading } \\
80-99= \pm 10 \% \\
\text { of reading }\end{array}$ \\
\hline Calibration interval & $\begin{array}{l}\text { Weekly or if } \\
\text { switching } \\
\text { adapter type }\end{array}$ & $\begin{array}{l}\text { If required, on } \\
\text { reference cells }\end{array}$ & $\begin{array}{l}\text { Weekly or if } \\
\text { switching } \\
\text { adapter type }\end{array}$ & Annually & $\begin{array}{l}\text { Annually, no } \\
\text { user calibration } \\
\text { required }\end{array}$ & Bi-annually \\
\hline Zero and span calibration & $\begin{array}{l}\text { Quick checks } \\
\text { any time on } \\
\text { reference cells }\end{array}$ & $\begin{array}{l}\text { Quick check } \\
\text { any time on } \\
\text { reference cells }\end{array}$ & $\begin{array}{l}\text { Quick check } \\
\text { any time on } \\
\text { reference cells }\end{array}$ & $\begin{array}{l}\text { Checks every } \\
3 \text { mo calibra- } \\
\text { tion gas }\end{array}$ & $\begin{array}{l}\text { Checks if required } \\
\text { with test gases }\end{array}$ & $\begin{array}{c}0 \text { and } 10 \% \mathrm{CO}_{2} \\
\text { test gas air } \\
\text { balanced }\end{array}$ \\
\hline Display range and units & $\begin{array}{l}0-100 \mathrm{mmHg} \\
\mathrm{mmHg}\end{array}$ & $\begin{array}{l}-4 \text { to } 150 \mathrm{mmHg} \\
\mathrm{mmHg} / \mathrm{kPa}\end{array}$ & $\begin{array}{l}0-100 \mathrm{mmHg} \\
\mathrm{mmHg} / \% / \mathrm{kPa}\end{array}$ & $\begin{array}{c}0-13 \% / 0-99 \\
\mathrm{mmHg} \\
\mathrm{mmHg} / \% / \mathrm{kPa}\end{array}$ & $\begin{array}{l}0-99 \mathrm{mmHg} \\
\mathrm{mmHg} / \% / \mathrm{kPa}\end{array}$ & $\begin{array}{l}0-99 \mathrm{mmHg} \\
\mathrm{mmHg} / \%\end{array}$ \\
\hline Display insp. $\mathrm{CO}_{2}$ & No & Yes & No & Yes & No & Yes \\
\hline $\begin{array}{l}\text { Barometric pressure compensa- } \\
\text { tion }(\mathrm{mmHg})\end{array}$ & $\begin{array}{l}\text { Auto/man } \\
\text { adjustable } \\
550-780\end{array}$ & $\begin{array}{l}\text { Man setting } \\
\text { altitude } \\
0-4600 \mathrm{~m}\end{array}$ & Man $500-800$ & $\begin{array}{l}\text { Man setting for } \\
\text { cal auto ad- } \\
\text { justment }\end{array}$ & Auto 0-3048 m & Auto $540-810$ \\
\hline Compensation for $\mathrm{N}_{2} \mathrm{O}$ & $\begin{array}{l}\text { Selectable } \\
50-70 \%\end{array}$ & Selectable & Selectable & Selectable & Selectable & Selectable \\
\hline Compensation for $\mathrm{O}_{2}$ & $\begin{array}{l}\text { Selectable } \\
\quad \geq 60 \%\end{array}$ & $\begin{array}{l}\mathrm{FiO}_{2} \text { driven or } \\
\text { assumed } 45 \%\end{array}$ & $\begin{array}{l}\text { Selectable } \\
0,21,40,60,80 \text {, } \\
100 \%\end{array}$ & No & Selectable $>60 \%$ & $\begin{array}{l}\text { Selectable } \\
\geq 50 \%\end{array}$ \\
\hline $\begin{array}{l}\text { Correction for water vapor } \\
\text { pressure }(47 \mathrm{mmHg})\end{array}$ & No & Yes & No & No & $\begin{array}{l}\text { Yes (mmHg } \\
\text { and kPa) } \\
\text { No (vol \%) }\end{array}$ & $\begin{array}{l}\text { Not yet, a cor- } \\
\text { rection will be } \\
\text { considered }\end{array}$ \\
\hline Continuous digital display & No & $\begin{array}{l}\text { Yes, but only in } \\
\text { the cal mode }\end{array}$ & No & No & No & Yes \\
\hline Airway adapter reusable & Yes & $\begin{array}{l}\text { Yes (metallic, } \\
\text { new plastic) }\end{array}$ & Yes & No & No & No \\
\hline Dead space (ml) & $\leq 5$ & $\begin{array}{l}15(\text { new } 7) \\
\text { neonatal } 2\end{array}$ & $\begin{array}{l}<5,<0.5 \text { neo- } \\
\text { natal }\end{array}$ & 7 & $<6$ & $\leq 5$ \\
\hline Sensor temperature $\left({ }^{\circ} \mathrm{C}\right)$ & 42 & $\begin{array}{l}41.7 \text { (motor), } 33 \\
\text { (window) }\end{array}$ & 42 & 42 & 42 & 42 \\
\hline Sensor chopped & No & $\begin{array}{l}\text { Yes, with cal } \\
\text { memory }\end{array}$ & No & Yes & Yes & $\begin{array}{l}\text { Yes, with cal } \\
\text { memory }\end{array}$ \\
\hline Operation temperature $\left({ }^{\circ} \mathrm{C}\right)$ & $10-40$ & $17-38$ & $10-40$ & $10-35$ & $10-40$ & $10-40$ \\
\hline Warm up time (sec) & 30 & $\begin{array}{l}20 \text { min full } \\
\text { accuracy }\end{array}$ & $300 \mathrm{~min}$ & 30 & 45 & $\leq 120$ \\
\hline Analogue output & Optional & Optional & Optional & No & Yes & No \\
\hline
\end{tabular}


TABLE VI Manufacturers' specification of the tested non clinical carbon dioxide analyser used as a reference device

\begin{tabular}{|c|c|}
\hline Product & Servomex 2500 Infrared Analyser \\
\hline Country of origin & Great Britain \\
\hline Manufacturer & Servomex \\
\hline General Description & The Servomex 2500 is a single beam, multiwavelength infrared to soft UV process analyser \\
\hline Uses & $\begin{array}{l}\text { suitable for monitoring single components or a component group in a gas or liquid sample } \\
\text { stream. It is supplied configured to the customers' precise analytical requirements for a stated } \\
\text { analysis in a background stream. }\end{array}$ \\
\hline Environment & Designed for $24 \mathrm{~h} /$ day continuous operation for industrial environments. \\
\hline Intrinsic error (under reference conditions) & Less than $\pm 1 \%$ of full scale deviation (fsd) $(1-100 \%)$ \\
\hline Calibration & $\begin{array}{l}\text { Factory calibration for the measurement required }\left(\mathrm{CO}_{2}\right) \text {. It contains a zero constant, a span } \\
\text { constant and a linearising function. Adjustments to each of these, using the calibration } \\
\text { routines, is possible. Test gas for zero and span required. }\end{array}$ \\
\hline Repeatability/linearity error & $\pm 0.5 \%$ fsd $/$ less than $1 \%$ fsd \\
\hline Output fluctuation (noise)/response time & Less than $1 \%$ fsd (peak-peak) at $\mathrm{T} 63=1 \mathrm{sec}$ \\
\hline Short term zero drift & Less than $\pm 1 \%$ fsd per week \\
\hline Ambient temperature/humidity & $0-55 \%$ (with heated cells above $100^{\circ} \mathrm{C}$ ) $/ 0-95 \%$, non-condensing \\
\hline Warm-up time/cell temp & Typically $2-10 \mathrm{~h}$, depending on application and environment. $/ 60^{\circ} \mathrm{C}$ \\
\hline Response time (T63) & User adjustable from 1-60s (electronic only, excludes sampling) \\
\hline Unit/range/resolution & Percent $/ 0-100 \% / 0.01 \%$ (actual span calibration: $10 \% \mathrm{CO}_{2}$ ) \\
\hline Sample flow $\max / \min$ (no internal pump) & $0.1-1.0 \mathrm{~L} \cdot \mathrm{min}^{-1}$ (liquid applications) $0.2-2.0 \mathrm{~L} \cdot \mathrm{min}^{-1}$ (gas applications) \\
\hline Sample pressure/temperature stability & $\pm 1.5 \%$ fsd for a $\pm 1 \%$ change in sample pressure $/ \pm 0.3 \%$ fsd for $\pm 1^{\circ} \mathrm{C}$ \\
\hline Power supply effects: voltage/ frequency & Less than $\pm 1 \%$ fsd for $10 \%(110 / 220 \mathrm{VAC}) /<1 \%$ fsd for $47-53 \mathrm{~Hz}$ or $57-63 \mathrm{~Hz}$ change. \\
\hline Analogue output & Each analogue output can be scaled across the whole measurement range (e.g., $0-100 \%$ ) \\
\hline
\end{tabular}

